\title{
A VIABILIDADE CONSTITUCIONAL DA ADOÇÃO DO PARLAMENTARISMO NO BRASIL: O PERENE DILEMA INSTITUCIONAL BRASILEIRO EM SEUS ASPECTOS HISTÓRICOS, JURÍDICOS E POLÍTICOS
}

\section{THE CONSTITUTIONAL FEASIBILITY OF THE ADOPTION OF PARLIAMENTARIANISM IN BRAZIL: HISTORICAL, LEGAL AND POLITICAL ASPECTS OF THE EVERLASTING BRAZILIAN INSTITUTIONAL DILEMMA}

LEONARDO SIMCHEN TREVISAN ${ }^{1}$ José AlCEBÍADES DE OLIVEIRA JUNIOR ${ }^{2}$

RESUMO: O presente estudo trata da viabilidade de uma mudança no sistema de governo no quadro da vigente Constituição da República Federativa do Brasil. Levando em consideração aspectos históricos, jurídicos e políticos, ele busca resgatar o pensamento de autores clássicos da teoria constitucional brasileira acerca do melhor sistema de governo para o país, se o presidencialismo ou o parlamentarismo, e contextualizá-lo na presente conjuntura, expondo um juízo afirmativo a respeito da possibilidade de uma alteração que, por obra do poder constituinte derivado, promova a substituição do atual regime de governo. Sustenta, da mesma forma, que a superação do presidencialismo, modelo institucional anacrônico, rígido e esgotado, e a concomitante adoção do parlamentarismo, sistema muito mais agregador e dinâmico, além de possível juridicamente, é igualmente oportuna do ponto de vista político-institucional. Sua implantação no Brasil poderia, nesse sentido, ser vista como um imperativo de racionalidade das instituições, contribuindo decisivamente para a superação do atual quadro de instabilidade e crise política, de modo a propiciar a consolidação e o aprofundamento da jovem democracia brasileira.

${ }^{1}$ Mestre (2016) e Doutor (2020) pelo Programa de Pós-Graduação em Direito da Universidade Federal do Rio Grande do Sul. Advogado.

${ }^{2}$ Realizou ciclo de estudos em nível de pós-doutorado na Justus-Liebig-Universität Giessen, Alemanha, em 2015. Doutor em Direito pela Universidade Federal de Santa Catarina (1991). Mestre em Instituições Jurídico-Políticas pela Universidade Federal de Santa Catarina (1984). Professor convidado permanente do Programa de Pós-Graduação em Direito da Universidade Federal do Rio Grande do Sul e Professor permanente do Programa de Pós-Graduação em Direito da Universidade Regional Integrada do Alto Uruguai e das Missões. 
PALAVRAS-CHAVE: crise política; parlamentarismo; presidencialismo.

ABSTRACT: The object of this essay entails the possibility of a change in the system of government within the framework of the current Constitution of the Federative Republic of Brazil. Taking into account historical, legal and political aspects, the study aims to give a new significance to the thinking of important scholars on the field of Brazilian constitutional theory, especially regarding the discussion about the best system of government, presidentialism or parliamentarianism. It seeks altogether to contextualize the controversy, arguing that, through constitutional amendment, such modification is perfectly viable. The replacement of presidentialism, an anachronistic, rigid and exhausted institutional model, by parliamentarianism, much more aggregating and dynamic, is not only possible from a constitutional point of view, but also politically convenient. The adoption of parliamentarianism in Brazil could be seen as an imperative of institutional rationality and a decisive measure for the country to overcome the current situation of instability and political crisis, in order to consolidate and improve the recent Brazilian democratic regime.

KEYWORDS: political crisis; parliamentarianism; presidentialism.

\section{INTRODUÇÃO}

Em 26 de outubro de 2014, a então presidente da República Federativa do Brasil e candidata à reeleição, Dilma Rousseff, do Partido dos Trabalhadores (PT), venceu Aécio Neves, do Partido da Social Democracia Brasileira (PSDB), no segundo turno da eleição presidencial, obtendo 54.501 .118 votos, contra 51.041 .155 do seu oponente (totalizando, respectivamente, 51,64\% e 48,36\% dos votos válidos). A vitória por uma pequena margem (o resultado mais equilibrado de uma eleição presidencial desde a redemocratização do país) prenunciava as dificuldades que a presidente reeleita teria de enfrentar ao longo de seu segundo mandato.

A posse de Rousseff, em 1o de janeiro de 2015, ocorreu em meio a uma grave crise econômica, que logo se converteria em crise institucional. O declínio dos indicadores econômicos somou-se à crescente insatisfação da população e a protestos pela sua saída do cargo, de modo a provocar, pouco depois da posse, a queda na popularidade da presidente reeleita a níveis dramaticamente baixos. A situação agravou-se nos meses subsequentes, e, em 02 de dezembro daquele ano, o então presidente da Câmara dos Deputados, Eduardo Cunha, aceitou o pedido de impeachment de Rousseff apresentado pelos juristas Hélio Bicudo, Janaína Paschoal e Miguel Reale Júnior.

No dia 17 de abril de 2016, o plenário da Câmara dos Deputados manifestou-se favoravelmente ao impeachment da então presidente, com 367 votos a favor e 137 
POLÍTICOS

contra. O pedido foi, então, remetido ao Senado Federal, que, no dia 12 de maio, decidiu, por 55 votos a 22, abrir o processo de impeachment, provocando o afastamento de Rousseff do cargo, assumido interinamente pelo então vicepresidente, Michel Temer. O processo foi julgado em 31 de agosto de 2016, ocasião na qual o Senado Federal determinou, por 61 votos a 20, o impeachment de Rousseff, seguindo-se a posse definitiva de Temer como presidente da República.

Mesmo após o fim do mandato de Temer, sucedido por Jair Bolsonaro, presidente eleito com 57.797.847 votos no segundo turno do pleito realizado em 2018, os efeitos da crise política (que parecia ter atingido seu ápice em 2016) não cessaram; ao contrário, eventos recentes demonstram que, sob todos os aspectos, a situação de instabilidade política no Brasil agravou-se desde então.

Do ponto de vista das instituições, essa crise permite diagnosticar com clareza as falhas históricas do presidencialismo no país. Semelhantes deficiências, já há muito tempo denunciadas por grandes nomes da teoria constitucional brasileira, não passaram despercebidas por alguns agentes políticos, como na Proposta de Emenda à Constituição n. ${ }^{\circ}$ 09, de 2016, arquivada ao final da respectiva legislatura, e na Proposta de Emenda à Constituição n. ${ }^{\circ}$ 217, de 2019, em tramitação no presente momento. Subjacente a ambas as propostas é a implantação do sistema parlamentarista de governo no país.

Permanece, entretanto, a dúvida a respeito da possibilidade de tal alteração do ponto de vista constitucional. O Supremo Tribunal Federal esteve muito próximo de pacificar a questão em junho de 2018, ocasião na qual deveria afirmar a constitucionalidade ou a inconstitucionalidade da mudança no sistema de governo, mas o julgamento da ação em que esse problema era discutido, o Mandado de Segurança (MS) 22972/DF, acabou prejudicado pela desistência do impetrante.

Diante disso, o presente estudo tem a intenção de oferecer uma resposta à questão da viabilidade da implementação do sistema parlamentarista de governo no Brasil, bem como apreciar a idoneidade dessa solução para a grave crise política que o país atravessa. Espera-se, com isso, prestar uma contribuição, ainda que modesta, para o debate institucional que deve ser travado no país em um momento tão delicado quanto o presente. No escopo de tornar essa contribuição tão abrangente quanto possível, aspectos históricos, jurídicos e de teoria política serão igualmente levados em consideração.

Sendo essa a proposta, a execução do presente trabalho dar-se-á em dois capítulos. No primeiro, serão apresentados os dois sistemas de governo, parlamentarismo e presidencialismo, cada um deles em suas características essenciais, ao lado das experiências de ambos os sistemas ao longo da história política do Brasil. No segundo, tratar-se-á especificamente das questões envolvendo a alteração do regime de governo no atual quadro constitucional, lançando-se o olhar sobre sua viabilidade e sua conveniência. 


\section{SISTEMAS DE GOVERNO: PRESIDENCIALISMO E PARLAMENTARISMO}

Diz Montesquieu (2004, p. 169): “Quando, na mesma pessoa ou no mesmo corpo de Magistratura, o Poder Legislativo é reunido ao Executivo, não há liberdade. Porque pode temer-se que o mesmo Monarca ou o mesmo Senado faça leis tirânicas para executá-las tiranicamente." Inspirando-se na organização política da Inglaterra, o grande artífice da teoria da divisão dos Poderes sublinha a necessidade de separação entre o poder de fazer as leis, corrigi-las e revogá-las (Legislativo) e o de executar as resoluções públicas (Executivo), sem a qual não pode subsistir a liberdade política do cidadão. (MONTESQUIEU, 2004, p. 169-170). ${ }^{3}$

Estabelecida a necessidade de separação dos Poderes Legislativo e Executivo, o passo seguinte consiste em determinar as peculiaridades de seu relacionamento. As relações possíveis entre o Legislativo e o Executivo dão origem aos distintos sistemas (ou regimes) de governo, que se diferenciam conforme a técnica adotada para a coordenação desses Poderes; em linhas gerais, pode ela ser de uma maior independência ou de uma maior colaboração. Os sistemas de governo predominantes, presidencialismo e parlamentarismo, materializam essas duas tendências: a independência entre os Poderes é a marca do sistema presidencial, ao passo que a colaboração é a tônica do sistema parlamentar. (SILVA, 2009, p. 505).

A seguir, os dois sistemas de governo serão analisados isoladamente.

\subsection{Presidencialismo}

O traço essencial do presidencialismo é a cumulação das funções de Estado, governo e administração em uma única autoridade, o chefe do Poder Executivo. Veja-se, a propósito, a enumeração das características do presidencialismo elaborada por José Afonso da Silva (2009, p. 505-506):

(a) é típico das Repúblicas; (b) o Presidente da República exerce o Poder Executivo em toda a sua inteireza; acumula as funções de Chefe do Estado, Chefe do Governo e Chefe da Administração Pública; cumpre um mandato por tempo fixo; não depende da confiança do órgão do Poder Legislativo nem para a sua investidura, nem para o exercício do governo; (c) o órgão do Poder Legislativo (Congresso, Assembleia, Câmara) não é Parlamento; seus membros são eleitos por período fixo de mandato; não está sujeito a dissolução; (d) as relações entre ambos os poderes são mais rígidas, prevalecendo o princípio da divisão de poderes

\footnotetext{
${ }^{3}$ Aos Poderes Legislativo e Executivo, Montesquieu (2004, p. 168-170) acresce um terceiro, o poder de punir os delitos e julgar as controvérsias entre os cidadãos (Judiciário). Salienta, ao mesmo tempo, que também esse poder deve ser separado dos demais, para evitar a degeneração do poder do Estado em tirania.
} 
POLÍTICOS

independentes e autônomos, embora possam ser harmônicos; (e) os Ministros de Estado são simples auxiliares do Presidente da República que os nomeia e exonera ao seu livre alvedrio (salvo injunções políticas); agem, cada qual, como chefe de um grande departamento administrativo, o seu Ministério, exercendo suas funções, cada qual por si, isoladamente; o Ministério (conjunto dos ministros) não tem organicidade, despachando cada Ministro com o Presidente da República sobre seus problemas, sem levar em conta as conexões com os outros; (f) eventual plano de governo, mesmo quando aprovado por lei, depende exclusivamente da coordenação do Presidente da República, que o executará ou não, bem ou mal, sem dar satisfação jurídica a outro poder (a não ser em prestações de contas financeiras e orçamentárias anuais, a posteriori); e se o executa mal, ou mesmo não o executa, continuará Presidente da República e os Ministros continuarão Ministros enquanto de sua confiança.

No plano histórico, a origem do presidencialismo deve ser buscada no artigo $2^{\underline{0}}$ da Constituição dos Estados Unidos da América, de 17 de setembro de 1787, que, laconicamente, estabelece a entrega do Poder Executivo ao presidente, a duração de seu mandato, a forma de eleição, as atribuições presidenciais (quase todas elas inerentes à chefia de Estado) e a possibilidade de sua destituição do cargo. A tímida regulamentação da instituição presidencial na Constituição deu margem ao seu desenvolvimento posterior na vida política dos Estados Unidos: o presidente deixou de exercer apenas funções de chefe de Estado, passando a ter papel ativo nos assuntos propriamente de governo, sendo-lhe entregue, ainda, o poder sobre a complexa e abrangente estrutura da administração federal. É o "governo de um homem só", autêntico "poder monárquico" em versão republicana. (HORTA, 2010, p. 652-653).

O grande sucesso dos Estados Unidos como nação ajudou a difundir o presidencialismo, especialmente entre os países latino-americanos que conquistaram sua independência no início do século XIX e, libertos do vínculo colonial, careciam de um modelo institucional no qual pudessem buscar inspiração. Em estudo comparativo acerca das instituições democráticas na América Latina, Diamond e Linz (1989, p. 24) asseveram:

Entre as instituições políticas comuns a todos os países latino-americanos, uma das mais proeminentes é a da, quase universal, democracia de tipo presidencial no lugar da parlamentar. Em termos comparativos, essa opção certamente merece destaque. Muitas das democracias europeias exitosas possuem sistemas parlamentaristas, assim como o Japão, a Índia e outras democracias da Comunidade Britânica. A América Latina é, com os Estados Unidos e alguns poucos países asiáticos, a única parte do mundo na qual a democracia foi institucionalizada (ou mesmo 
repetidamente experimentada) sob a forma de presidencialismo (e também a única parte onde o presidencialismo tem sido mesclado com a representação proporcional). Surpreendentemente, todavia, nos debates acerca das causas do fracasso democrático, não se dava, até recentemente, nenhuma atenção ao papel do governo presidencial, talvez porque ele tenha sido tão bem-sucedido nos Estados Unidos. As repúblicas latinoamericanas simplesmente transplantaram as instituições estadunidenses, sendo, por isso, tentador atribuir uma performance muito menos exitosa a outros fatores políticos, sociais e econômicos. [...] Uma das consequências intelectuais promissoras dos recentes períodos autoritários e da busca por arranjos democráticos estáveis tem sido uma renovada atenção [...] às instituições políticas, incluindo questões relativas à estrutura constitucional e esforços pela reforma constitucional em uma série de países. (Tradução livre.)

No Brasil, o presidencialismo foi adotado pela Constituição de 1891 e, desde então, vem perpassando a história institucional do país (com um pequeno intervalo na década de 60 do século passado), até chegar à atual Constituição, que o manteve. ${ }^{4}$

\subsection{Parlamentarismo}

Segundo Raul Machado Horta (2010, p. 635), as características fundamentais do sistema parlamentarista de governo são:

I - existência de um Chefe de Estado politicamente irresponsável;

II - responsabilidade política dos Ministros perante o Parlamento;

III - órgão coletivo formado pelos Ministros - Conselho de

Ministros ou Gabinete - sob a direção do Presidente do Conselho,

Primeiro-Ministro ou Chanceler;

IV - técnicas de ação recíproca de um Poder sobre o outro, especialmente a questão de confiança, a moção de censura, a interpelação, a questão oral, a dissolução das Câmaras ou de uma delas pelo Chefe de Estado;

V - dualidade de órgãos do Poder Executivo - o Chefe de Estado (Monarca ou Presidente da República) e o Chefe de Governo (Primeiro-Ministro, Presidente do Conselho de Ministros, Chanceler).

Do ponto de vista político, o traço mais importante do parlamentarismo é, como o próprio nome sugere, a amplitude das funções do Poder Legislativo, pois o parlamento não apenas compreende o chefe de governo e seu conselho de ministros,

\footnotetext{
4 Ver item 1.3, infra.
} 
POLÍTICOS

mas também dispõe de grandes poderes sobre a formação e a continuidade do governo: a escolha do primeiro-ministro depende da maioria parlamentar, e, como ele não dispõe de um mandato (pode permanecer no cargo indefinidamente ou dele ser privado logo após sua investidura), só poderá manter-se no poder enquanto dispuser do apoio e da confiança do parlamento (por sua vez, responsável politicamente perante o eleitorado). (SILVA, 2009, p. 506-507).

Menção seja feita, aqui, à "fórmula lapidar de Raul Pilla, ao contrastar o parlamentarismo com o presidencialismo: o primeiro, dizia ele, é o governo da responsabilidade a prazo incerto; o segundo, o governo da irresponsabilidade a prazo certo." (BONAVIDES, 2008, p. 213).

\subsubsection{Parlamentarismo monárquico e parlamentarismo republicano}

Uma primeira distinção que pode ser feita no âmbito do parlamentarismo diz respeito à possibilidade de sua adoção conjugada com diferentes formas de governo (monarquia e república); embora desprovida de caráter analítico, ela ajuda a compreender esse sistema de governo em seu aspecto histórico.

Quanto ao parlamentarismo monárquico, verifica-se que a monarquia constitucional está na gênese do parlamentarismo, podendo-se falar até mesmo em uma relação de causalidade entre eles; o sistema parlamentarista de governo é produto do processo histórico de limitação do poder real e da concomitante ampliação dos poderes do parlamento. Trata-se de um processo cujas origens podem ser buscadas no Reino Unido das décadas finais do século XVII e, subsequentemente, nas monarquias constitucionais do século XIX. (HORTA, 2010, p. 616).

Como sói acontecer com as instituições britânicas, o parlamentarismo no Reino Unido "é fruto de uma larga paciência, de um lento e constante trabalho de perfeição". (ALVES FILHO, 1961, p. 21). Ao longo do século XVIII, o sistema político britânico experimentou diversas inovações que o levaram em direção ao parlamentarismo (como o surgimento da figura do "primeiro-ministro", o ministro mais próximo do rei, ocorrido em razão das dificuldades de comunicação de George I, que não dominava a língua inglesa, bem como a queda do gabinete chefiado por Lord North, em decorrência de voto de desconfiança do parlamento). (HORTA, 2010, p. 615-619). Contudo, um governo de gabinete propriamente dito, livre de qualquer interferência do monarca, consolidou-se no Reino Unido apenas a partir da reforma eleitoral de 1832, que, através do sistema de partidos, criou as condições necessárias para que a escolha do primeiro-ministro passasse exclusivamente às mãos do eleitorado, excluindo-se dela o soberano. (PILLA, 1992, p. 30). 
A experiência britânica preparou o terreno para a implantação, ao longo do século XIX, do sistema parlamentarista em outras monarquias europeias, todas elas confrontadas com a necessidade de uma limitação crescente do poder real. $\mathrm{Na}$ França, ele foi implantado através da Constituição de 04 de junho de 1814, outorgada por Luís XVIII no contexto da assim chamada "Restauração Monárquica", e manteve-se na Constituição da monarquia orleanista, de 14 de agosto de 1830. Na mesma senda, o parlamentarismo foi consagrado como sistema de governo na Constituição da Bélgica, de 07 de fevereiro de 1831, na Constituição de Luxemburgo, de 17 de outubro de 1868, na Constituição da Noruega, de 17 de maio de 1814, e na Constituição da Holanda, de 30 de novembro de 1887. Comum a essas Constituições é a circunstância de disciplinarem o parlamentarismo apenas de forma rudimentar; em lugar de uma organização sistemática e detalhada do funcionamento do regime, deram preferência a um "parlamentarismo consuetudinário", desenvolvido, sobretudo, através de convenções constitucionais, muito mais importantes para a prática do regime que as lacônicas disposições constitucionais a respeito dele - um espelho do que já ocorria com o parlamentarismo britânico. (HORTA, 2010, p. 616-617). Além das fronteiras da Europa, o parlamentarismo monárquico chegou ao Brasil, que o adotou como sistema de governo na Constituição Imperial de $1824 .{ }^{5}$

Quanto ao parlamentarismo republicano, embora guarde suas origens na Constituição da Terceira República Francesa, de 25 de fevereiro de 1875, trata-se de fenômeno típico do século XX, inserindo-se no contexto daquilo que MirkineGuetzévitch (1933, p. 45-53) denomina "racionalização do poder". Analisando as Constituições europeias posteriores à Primeira Grande Guerra, o referido autor conclui existir uma tendência, forjada pelos ideais do Estado de Direito e da democracia, de tornar o poder cada vez mais racionalizado, no sentido de uma progressiva submissão de toda a vida política ao direito, particularmente visível nas formulações de parlamentarismo que se encontram naquelas Constituições: um arranjo institucional regulado de maneira nítida e circunstanciada, cujo funcionamento deixou de ser um assunto político para converter-se em tema propriamente jurídico.

Pode-se dizer que o parlamentarismo republicano, sendo posterior ao parlamentarismo monárquico, tomou deste as técnicas do regime, modelando-as (a uma nova forma de governo, a republicana, que se alastrou pela Europa com o declínio das monarquias nacionais após a Primeira Grande Guerra) e racionalizando-as (com a substituição das convenções constitucionais não escritas

${ }^{5}$ Ver item 1.3.2.1, infra. 
POLÍTICOS

por extenso regramento no próprio texto constitucional). Exemplos dessa tendência podem ser buscados, em uma primeira fase, na Constituição da Alemanha de 1919, na Constituição da Áustria de 1920 e na Constituição da República Espanhola de 1931; posteriormente à Segunda Grande Guerra, o parlamentarismo republicano permaneceria nas Constituições da França de 1946 e 1958, na Lei Fundamental da República Federal da Alemanha de 1949 e ampliaria sua influência para outros países, sendo adotado na Constituição da República Italiana de 1947 e na Constituição da República Portuguesa de 1976. (HORTA, 2010, p. 637). O Brasil não escapou a essa influência, experimentando o parlamentarismo em um breve período de sua história republicana, de 1961 a $1963 .{ }^{6}$

\subsubsection{Parlamentarismo monista e parlamentarismo dualista}

Uma segunda distinção a fazer no âmbito do parlamentarismo diz respeito à sua configuração do ponto de vista da distribuição de competências entre a chefia de Estado e a chefia de governo. Duas são, por esse prisma, as modalidades básicas de parlamentarismo: monista e dualista.

O parlamentarismo monista é aquele onde o chefe de Estado limita-se a exercer um papel quase integralmente simbólico, como o máximo representante da nação, artífice da unidade do Estado acima das disputas político-partidárias; o monopólio da autoridade de governo cabe ao gabinete, notadamente ao primeiro-ministro. Constitui indubitavelmente a forma mais pura e democrática de parlamentarismo. (BONAVIDES, 2008, p. 211-212).

O clássico exemplo de parlamentarismo monista é o sistema de governo adotado hoje no Reino Unido, resultante de um longo processo histórico cujo início foi marcado pela preponderância do parlamentarismo dualista. (BONAVIDES, 2008, p. 212). Também a Alemanha, com a Lei Fundamental de 1949, adotou o parlamentarismo monista, concedendo ao presidente federal não mais do que competências rigorosamente limitadas, entre as quais não está incluída uma participação ativa e determinante na condução dos assuntos do Estado; ela cabe exclusivamente ao governo federal, cujo posto central é ocupado pelo chanceler. (HESSE, 1998, p. 479-480).

Por sua vez, o parlamentarismo dualista caracteriza-se por um papel mais ativo do chefe de Estado, que, ao lado de suas funções tipicamente simbólicas, enfeixa determinadas atribuições políticas. É característica desse sistema a apuração da responsabilidade política do governo tanto diante do parlamento quanto do chefe de Estado. (HORTA, 2010, p. 612). Essa modalidade de parlamentarismo pressupõe uma repartição equilibrada das competências governativas entre o chefe de Estado e o primeiro-ministro; quando isso não ocorre, um dos polos de poder tende a preponderar sobre o outro, atrofiando-se, assim, a índole parlamentarista do sistema. (BONAVIDES, 2008, p. 212).

${ }^{6}$ Ver item 1.3.2.2, infra. 
Como modelo representativo de parlamentarismo dualista pode ser citado o sistema adotado na França com a chamada "Monarquia de Julho", que, em 1830, representou a ascensão de Luís Filipe d'Orleães ao trono (por essa razão, o parlamentarismo dualista recebe por vezes o nome de "orleanista"). (HORTA, 2010, p. 612). No século XX, a Alemanha conheceu um parlamentarismo de inspiração dualista durante o período da chamada "República de Weimar": a Constituição de 1919 procurou conferir ao presidente imperial, escolhido através de eleição popular direta, com um extenso período de mandato e amplas competências na esfera política, uma influência significativa sobre decisões propriamente de governo. (HESSE, 1998, p. 479). Ela pode ser considerada um prelúdio ao neoparlamentarismo contemporâneo, que, seguindo seu exemplo, é extremamente generoso na concessão de poderes políticos ao chefe de Estado (ou seja, o presidente, razão pela qual esse sistema foi batizado de "semipresidencialismo"), legitimado democraticamente por meio de eleições diretas (ao contrário do que ocorre no parlamentarismo republicano monista, onde o chefe de Estado é eleito pelo próprio parlamento, ou por representantes escolhidos especialmente para essa finalidade). O marco dessa concepção de parlamentarismo é a Constituição da República Francesa de 1958, que consagrou o pensamento político do general Charles de Gaulle. (HORTA, 2010, p. 613).

\subsection{Presidencialismo e parlamentarismo ao longo da história institucional do Brasil}

A história das instituições brasileiras é peculiar, marcada por grandes oscilações entre formas de conceber a divisão de Poderes (e, consequentemente, entre distintos sistemas de governo), sem que uma tradição estável e ininterrupta ao longo da evolução política do país possa ser vislumbrada. O tema será objeto das reflexões seguintes.

\subsubsection{Visão geral}

Durante os séculos em que esteve sujeito ao domínio colonial português, o Brasil não conheceu a divisão de Poderes; nas palavras de Celso Agrícola Barbi (2009, p. 25), "a monarquia lusitana tinha caráter absoluto e o Executivo absorvia em si todos os Poderes, ou, como dizia o Visconde do Uruguai, havia um só Poder." Antes de sua independência, o Brasil experimentou apenas a concentração dos Poderes, enfeixados nas mãos do soberano do Império Português.

Proclamada a independência, a Constituição do Império do Brasil, de 25 de março de 1824, adotou o parlamentarismo como sistema de governo. No plano constitucional, isso significou a institucionalização, ao lado dos Poderes Executivo, Legislativo e Judiciário, do Poder Moderador, delegado privativamente ao Imperador e descrito como a chave de toda a organização política. 
POLÍTICOS

Com a queda do Império, o constituinte republicano de 1891 optou por institucionalizar, no plano constitucional, o presidencialismo: o artigo 37 daquela Constituição referia-se ao Presidente dos Estados Unidos do Brasil como o chefe eletivo e supremo da nação. A partir de então, o presidencialismo foi consagrado como sistema de governo em todas as Constituições posteriores (democráticas ou não) que o país conheceu, incluindo-se a atual. (HORTA, 2010, p. 653).

\subsubsection{As experiências de parlamentarismo no Brasil}

Ao longo de sua história, o Brasil passou por duas experiências de parlamentarismo: uma duradoura e estável no Império, outra efêmera e tumultuada na República. A seguir, ambas serão expostas em seus traços essenciais.

\subsubsection{O parlamentarismo do Segundo Reinado}

A primeira experiência de parlamentarismo no Brasil remonta ao século XIX, durante o período monárquico de sua história; embora juridicamente arrimado na Constituição de 1824, o sistema parlamentarista desenvolver-se-ia no país apenas no Segundo Reinado (1840-1889). Dizer que a Constituição do Império conferia sustentação jurídica ao parlamentarismo, contudo, não equivale a dizer que ela o previa expressamente: nenhuma menção a esse sistema de governo podia ser extraída de seu texto. (TORRES, 1962, p. 49). ${ }^{7}$

Sobre as particularidades da configuração constitucional do regime de governo adotado no Brasil Império, Raul Machado Horta (2010, p. 614) esclarece:

A Constituição do Império de 1824 seguiu o exemplo de outras Constituições monárquicas do século XIX, omitindo-se sobre as regras do regime parlamentar. Entre as atribuições do Poder Moderador, "delegado privativamente ao Imperador" (art. 98), figurava a de nomear e demitir livremente os Ministros de Estado (art. 101, 6º $)$. O Imperador era o Chefe do Poder Executivo (art. 102) e os Ministros de Estado instrumentos de seu exercício. A responsabilidade dos Ministros se apuraria na prática de delitos, que a Constituição enumerava (arts. 133 e 134). A Presidência do Conselho de Ministros, que a Constituição do Império ignorou, foi objeto de criação pelo Decreto Imperial n. 523, de 20 de julho de 1847. O regime parlamentar no Segundo Reinado decorreu da prática parlamentar e das inspirações europeias do Imperador. Tivemos o parlamentarismo consuetudinário, produto das

\footnotetext{
7 João Camillo de Oliveira Torres (1962, p. 49-50) sustenta até mesmo como causa do insucesso político de Pedro I e do Regente Feijó o fato de ambos terem se mostrado refratários à interpretação parlamentarista da Constituição do Império; esse vício, segundo ele, seria sanado apenas nos primeiros anos do reinado de Pedro II.
} 
convenções e das experiências políticas, como aconteceu, de modo geral, no parlamentarismo do século XIX.

O teorizador da doutrina do poder neutro do monarca foi o político e intelectual francês (de origem suíça) Benjamin Constant. Contrapondo-se à tripartição de poderes formulada por Montesquieu, Constant (1820, p. 31-33) defendia a existência de quatro poderes constitucionais: o Real, o Representativo (Legislativo), o Executivo e o Judicial. Segundo ele, a diferenciação entre o Poder Real e o Poder Executivo correspondia à "chave de toda a organização política" (uma fórmula reproduzida ipsis verbis no artigo 98 da Constituição do Império ao tratar do Poder Moderador); separando-os, Constant acreditava solucionar o problema da sempre presente possibilidade de conflitos entre Executivo, Legislativo e Judiciário. Subjaz a isso a ideia de que semelhante conflito deve ser dirimido em uma instância estranha a esses Poderes, sob pena de inflar-se demasiadamente a competência de um deles, em prejuízo dos demais. Em uma monarquia constitucional, a neutralidade necessária para o desempenho dessa função somente poderia estar, para Constant, no Poder Real, cujo único interesse no âmbito das disputas políticas residiria em promover cooperação e diálogo entre os Poderes desavindos.

Sob a égide do Poder Moderador, personificado em Pedro II, o Brasil desenvolveu um sistema de governo parlamentarista de inspiração inglesa, ${ }^{8}$ sistema esse que, a despeito de suas imperfeições, representou para o país um grau de amadurecimento político que contrastava fortemente com as instáveis e tumultuosas repúblicas vizinhas da América do Sul. (AZEVEDO, 1934, p. 33). Apesar disso, o Poder Moderador sempre foi motivo de celeuma entre os doutrinadores brasileiros; ${ }^{9}$ alguns de seus mais severos críticos chegaram a defender que ele teria promovido uma desnaturação do parlamentarismo no país.

\footnotetext{
${ }^{8}$ A estrutura política, administrativa e judicial do Império era complexa, produto da interação entre fatores originários de tradições as mais diversas. Nas palavras de José Murilo de Carvalho (1990, p. 23), o "Império brasileiro realizara uma engenhosa combinação de elementos importados. Na organização política, inspirava-se no constitucionalismo inglês, via Benjamin Constant. Bem ou mal, a Monarquia brasileira ensaiou um governo de gabinete com partidos nacionais, eleições, imprensa livre. Em matéria administrativa, a inspiração veio de Portugal e da França, pois eram esses os países que mais se aproximavam da política centralizante do Império. $O$ direito administrativo francês era particularmente atraente para o viés estatista dos políticos imperiais. Por fim, até mesmo certas fórmulas anglo-americanas, como a justiça de paz, o júri e uma limitada descentralização provincial, serviam de referência quando o peso centralizante provocava reações mais fortes."

${ }^{9}$ Registre-se que, do ponto de vista do liberalismo político, as críticas ao Poder Moderador não são surpreendentes, já que ele inegavelmente dotava o soberano de poderes de colossal amplitude. $\mathrm{O}$ Imperador não apenas detinha as prerrogativas, acima referidas, de nomear e exonerar livremente
} 
POLÍTICOS

Paulo Bonavides é um dos mais enfáticos. Sustenta esse autor que o regime de governo adotado no Brasil Império seria meramente um "pseudoparlamentarismo", ou, quando muito, um "pré-parlamentarismo", no qual a sombra constante da vontade imperial, que arbitrariamente derrubava ministérios e dissolvia a Câmara, impedia a consolidação de um regime propriamente parlamentarista, erigido sobre a autoridade do Poder Legislativo uma situação desconfortável para o próprio Imperador, como foi visto, por exemplo, nos anos posteriores à crise de 1868, com a queda do gabinete Zacarias e a ascensão de Itaboraí, quando o caráter arbitrário da destituição fez crescer mesmo entre os conservadores a tese liberal que contestava a amplitude dos poderes imperiais. (BONAVIDES, 2008, p. 214-216).

Raul Pilla envereda por um caminho semelhante. Segundo ele, na medida em que a Constituição do Império, através do Poder Moderador, possibilitava ao Imperador nomear e demitir livremente os ministros, não tinha ela um caráter parlamentarista. Mais além, o referido autor atribui a instabilidade do regime de governo no Segundo Reinado (os gabinetes duravam em média 17 meses) não a pretensos defeitos do parlamentarismo enquanto tal, mas à ação pessoal do Imperador, que não hesitava em demitir ministérios mesmo quando apoiados pelo parlamento. (PILLA, 1992, p. 41-43).

Sob esse aspecto, dificilmente pode ser posto em dúvida que o parlamentarismo do Segundo Reinado apresentava um viés autocrático que não se coaduna com as características do sistema parlamentarista de governo. A configuração políticoinstitucional do Império do Brasil corresponde, porém, a fenômeno complexo. ${ }^{10}$

os ministros de Estado e encabeçar o Poder Executivo (ao qual toda a estrutura administrativa do país estava subordinada). O Poder Legislativo do Império era estruturado em duas casas, a Câmara e o Senado, ambas sujeitas à interferência do Imperador: quanto à primeira, era-lhe reservado o direito de dissolução; quanto ao segundo, cabia-lhe nomear os senadores (que, ao contrário dos deputados, eram vitalícios) a partir de lista tríplice encaminhada pelas províncias. Com relação ao Poder Judiciário, tinha o Imperador a faculdade de suspender os magistrados. Ainda, a rígida centralização do Império, sufocando a autonomia das províncias, deu ao Imperador controle político e administrativo sobre todos os quadrantes do país, através da nomeação, que a ele competia, dos presidentes das províncias e dos chefes de polícia (cujas atribuições eram bastante amplas, não se limitando à esfera policial, mas abarcando também determinadas funções judiciais). (SILVA, 2009, p. 75-76).

${ }^{10} \mathrm{Um}$ argumento a seu favor pode ser encontrado em João Camillo de Oliveira Torres. Defende o mencionado autor que o sistema adotado no Segundo Reinado tinha todas as características e vantagens do parlamentarismo, embora funcionasse de cima para baixo. E isso porque o sistema eleitoral do Império era extremamente deficiente, em razão de fatores jurídicos, políticos e principalmente - sociais: em um país ainda agrário e despovoado, onde as eleições podiam ser facilmente manipuladas pelos detentores do poder, uma certa "inautenticidade" da representação política era inevitável. Diante desse quadro, a ficção constitucional do caráter representativo do Imperador, autêntica nação encarnada, possibilitou que, ao serem responsáveis perante o 
Uma resposta definitiva a respeito do significado e do valor dessa experiência histórica demandaria investigação à parte; aqui, a questão pode ser deixada em aberto.

\subsubsection{O parlamentarismo republicano de 1961-1963}

Após décadas de república presidencial, o Brasil voltaria a adotar o parlamentarismo em 02.09.1961, com a previsão desse regime na Emenda n. .04 à Constituição de 1946. Não se tratou, contudo, de obra de engenharia institucional cuidadosamente planejada, e sim de uma solução de emergência para a superação da aguda crise desencadeada pela renúncia de Jânio Quadros à presidência. (HORTA, 2010, p. 656). Com efeito, pode-se dizer que o regime instituído pela Emenda Constitucional n. 04 (que passou à história com a denominação "Ato Adicional") não foi elaborado para funcionar a contento, como um autêntico parlamentarismo, mas representou tão somente uma resposta do Congresso à situação caótica daquele tempo, quando era premente a ameaça de uma guerra civil entre as forças contrárias e favoráveis à posse do vice-presidente João Goulart, ausente do país (em viagem oficial à China) ao tempo dos fatos. Foi "o único expediente possível para lograr naquele ensejo uma trégua entre correntes políticas passionais, cuja divisão punha em risco a segurança do País e o futuro das instituições". (BONAVIDES, 2008, p. 217).

O parlamentarismo instituído pelo Ato Adicional era de natureza dualista, prevendo como principais atos do presidente da República:

a) Nomear o Presidente do Conselho de Ministros e, por indicação deste, os demais Ministros de Estado, e exonerá-los quando a Câmara dos Deputados lhes retirar a confiança (Ato Adicional, art. $3^{\mathrm{o}}$, n.. 1 ), dependendo, no entanto, a "nomeação" do primeiro Ministro do pronunciamento favorável da maioria absoluta da Câmara dos Deputados (art. $8^{\circ}$ ), bem como da anuência do Senado, na forma do art. 10;

b) Presidir às reuniões do Conselho de Ministros, quando julgar conveniente (art. $3^{\circ}$, n. $\left.\frac{o}{2}\right)$;

\footnotetext{
Imperador, os gabinetes fossem simultaneamente responsáveis perante a nação. Essa ficção, todavia, apenas produziu bons frutos em razão das qualidades pessoais de D. Pedro II, que soube, com extrema acuidade e competência, encarnar a função simbólica e suprapolítica do monarca no exercício do Poder Moderador. Sob esse aspecto, o Imperador substituía um eleitorado cronicamente sub-representado. Tal peculiaridade possibilitou que o parlamentarismo imperial funcionasse a contento durante quase meio século, e é lícito pensar que teria evoluído para um parlamentarismo mais autêntico, baseado exclusivamente na vontade popular, se o presidencialismo não o tivesse suplantado. (TORRES, 1962, p. 50-54).
} 
c) Vetar, nos termos da Constituição, os projetos de leis (art. $3^{\circ}$, n. ${ }^{\circ}$ 4);

d) Representar a Nação perante Estados estrangeiros (art. 3º, n. ${ }^{\circ}$ );

e) Apresentar mensagens ao Congresso Nacional por ocasião da abertura de sessão legislativa expondo a situação do País (art. 3º n. ${ }^{\mathrm{o}} 12$ );

f) Conceder indultos e comutar penas com a audiência dos órgãos instituídos em lei;

g) Dissolver a Câmara dos Deputados quando comprovada a impossibilidade de manter-se o Conselho de Ministros, por falta de apoio parlamentar (art. 14);

h) Nomear um Conselho de Ministros de caráter provisório, quando dissolvida a Câmara (art. 14, $\S 1^{1}$ );

i) Prover, na forma da lei e com as ressalvas estatuídas pela Constituição, os cargos públicos federais (art. $3^{\circ}$, n. ${ }^{\circ} 14$ );

j) Nomear e exonerar os membros do Conselho de Economia (art. $3^{\text {o }}$, n. ${ }^{\circ}$ 16, in fine). (REALE, 1962, p. 15-16).

A extensão dessas competências permite afirmar que, em que pese a intenção do Congresso tenha sido a de subtrair poderes ao presidente, não foi ele transformado em figura meramente decorativa; embora privado da plenitude das funções de governo, conservava o chefe de Estado competências constitucionais bastante amplas, capazes até mesmo de embaraçar politicamente a atuação do primeiro-ministro. (BONAVIDES, 2008, p. 217-218).

João Goulart, todavia, não se conformou com o que via como um ilegítimo ataque à sua autoridade presidencial. A Emenda Constitucional n. ${ }^{\circ} 04$ previa que, no ano de 1965, seria realizado um plebiscito para definir a manutenção do parlamentarismo ou o regresso ao presidencialismo. Após um período de confusas manobras políticas e de agressivo apelo propagandístico, o plebiscito acabou sendo antecipado para janeiro de 1963, com o triunfo, desejado por Goulart, do presidencialismo. (HORTA, 2010, p. 656-657). Em atenção ao resultado da consulta popular, o Congresso promulgou a Emenda Constitucional n.o 06, de 23.01.1963, consumando a volta ao antigo regime de governo. (SILVA, 2009, p. 86).

No conjunto, pode-se dizer que, apesar do fato de ter surgido como solução de emergência a uma crise generalizada e de toda a resistência que enfrentou por parte dos detentores do poder, o parlamentarismo de 1961-1963 cumpriu a função para a qual havia sido desenhado. Em que pese ter conhecido três chefes de gabinete no período de um ano e três meses, o regime mostrou-se mais estável do que o presidencialismo restaurado em 1963, logrando êxitos políticos importantes, como a aprovação da Lei de Diretrizes e Bases da Educação Nacional (Lei 4.024, de 20.12.1961) e da Lei de Remessa de Lucros para o Exterior (Lei 4.131, de 03.09.1962); não fosse o descontentamento gerado na classe política pela extinção de um regime que possibilitava a vantagem do exercício do poder de forma unipessoal e 
monopolizadora, o parlamentarismo do Ato Adicional poderia ter sido bemsucedido. (BONAVIDES, 2008, p. 218).

A restauração do presidencialismo trouxe o aprofundamento da crise. Goulart ainda tentou, por um breve período, equilibrar-se no poder, embora sem sucesso; foi deposto por um golpe militar a $1^{\circ} .04 .1964$, que instaurou no país um regime autoritário de duas décadas de duração. (SILVA, 2009, p. 86). Tempos sombrios despontavam no horizonte; como assinala Horta (2010, p. 657), a "História Política do Brasil registrou as consequências que advieram da derrubada precipitada do regime parlamentar". Bonavides (2008, p. 223) descreve a ditadura subsequente como "filha bastarda do presidencialismo restaurado".

\subsubsection{O presidencialismo sob a Constituição de 1988}

O ocaso do regime autoritário instaurado no Brasil em 1964 (que, cumpre ressaltar, manteve intocado o sistema presidencialista, colhendo os frutos do seu viés autocrático) reavivou o debate acerca do melhor sistema de governo para o país. Cenário desse debate foi a Assembleia Nacional Constituinte, convocada pela Emenda Constitucional n. ${ }^{\circ}$ 26, de 27.11.1985, e escolhida através de eleição popular em 15.11.1986. Diferentemente do ocorrido nas Constituintes anteriores da República, todas elas quase unanimemente presidencialistas, a nova Constituinte foi ocupada por uma forte corrente parlamentarista, o que significou a preponderância do parlamentarismo em diversos documentos aprovados nas fases prévias da elaboração da Constituição. Apesar disso, reviravoltas políticas imprimiram um novo rumo à Constituinte, ${ }^{11}$ e o presidencialismo acabou sendo consagrado no texto final da Constituição, cujo artigo 76 estabelece que o Poder Executivo é exercido, com o auxílio dos Ministros de Estado, pelo Presidente da República. (HORTA, 2010, p. 657-659).

Nova derrota conheceria o parlamentarismo no plebiscito de 1993. Com o advento da nova Constituição, o artigo $2^{\circ}$ do Ato das Disposições Constitucionais Transitórias determinou a realização de um plebiscito, originalmente marcado para o dia 07.09.1993, no qual a população definiria a forma (república ou monarquia) e o sistema de governo (parlamentarismo ou presidencialismo) que a Constituição

\footnotetext{
${ }^{11}$ Foi precisamente no dia 22 de março de 1988 que a proposta de parlamentarismo foi derrotada, por 344 votos a 212, no âmbito da Assembleia Constituinte. (LAMOUNIER, 1991, p. 10). Juan José Linz e Alfred Stepan (1996, p. 169) assinalam que semelhante reviravolta ocorreu por meio de uma conjunção de forças entre os militares (que, a despeito do fim do regime ditatorial, não abriam mão de sua influência sobre os trabalhos da Assembleia Constituinte) e o então presidente José Sarney, ambos desfavoráveis à adoção de um sistema parlamentarista que limitasse os poderes presidenciais.
} 
POLÍTICOS

deveria adotar. Por força da Emenda Constitucional n. ${ }^{\circ}$ 02, de 1992, o plebiscito foi antecipado para 21.04.1993, traduzindo em seu resultado uma expressiva maioria a favor da república e do presidencialismo. (SILVA, 2009, p. 90). ${ }^{12}$

O sistema de governo presidencialista consagrado na atual Constituição é pródigo na atribuição de poderes ao presidente. Em seu artigo 84, estabelece:

Art. 84. Compete privativamente ao Presidente da República:

I - nomear e exonerar os Ministros de Estado;

II - exercer, com o auxílio dos Ministros de Estado, a direção superior da administração federal;

III - iniciar o processo legislativo, na forma e nos casos previstos nesta Constituição;

IV - sancionar, promulgar e fazer publicar as leis, bem como expedir decretos e regulamentos para sua fiel execução;

$\mathrm{V}$ - vetar projetos de lei, total ou parcialmente;

VI - dispor, mediante decreto, sobre:

a) organização e funcionamento da administração federal, quando não implicar aumento de despesa nem criação ou extinção de órgãos públicos;

b) extinção de funções ou cargos públicos, quando vagos;

VII - manter relações com Estados estrangeiros e acreditar seus representantes diplomáticos;

VIII - celebrar tratados, convenções e atos internacionais, sujeitos a referendo do Congresso Nacional;

IX - decretar o estado de defesa e o estado de sítio;

$X$ - decretar e executar a intervenção federal;

XI - remeter mensagem e plano de governo ao Congresso Nacional por ocasião da abertura da sessão legislativa, expondo a situação do País e solicitando as providências que julgar necessárias;

XII - conceder indulto e comutar penas, com audiência, se necessário, dos órgãos instituídos em lei;

XIII - exercer o comando supremo das Forças Armadas, nomear os Comandantes da Marinha, do Exército e da Aeronáutica, promover seus oficiais-generais e nomeá-los para os cargos que lhes são privativos;

XIV - nomear, após aprovação pelo Senado Federal, os Ministros do Supremo Tribunal Federal e dos Tribunais Superiores, os Governadores de Territórios, o Procurador-Geral da República, o

12 Paulo Bonavides (2008, p. 223-224) critica fortemente a antecipação da data de realização do plebiscito de 1993, salientando a sua inconstitucionalidade formal e material e indo tão longe a ponto de traçar um paralelo com a antecipação, de graves consequências, do plebiscito que derrubou o parlamentarismo em 1963. 
presidente e os diretores do Banco Central e outros servidores, quando determinado em lei;

XV - nomear, observado o disposto no art. 73, os Ministros do Tribunal de Contas da União;

XVI - nomear os magistrados, nos casos previstos nesta Constituição, e o Advogado-Geral da União;

XVII - nomear membros do Conselho da República, nos termos do art. 89, VII;

XVIII - convocar e presidir o Conselho da República e o Conselho de Defesa Nacional;

XIX - declarar guerra, no caso de agressão estrangeira, autorizado pelo Congresso Nacional ou referendado por ele, quando ocorrida no intervalo das sessões legislativas, e, nas mesmas condições, decretar, total ou parcialmente, a mobilização nacional;

XX - celebrar a paz, autorizado ou com o referendo do Congresso Nacional;

XXI - conferir condecorações e distinções honoríficas;

XXII - permitir, nos casos previstos em lei complementar, que forças estrangeiras transitem pelo território nacional ou nele permaneçam temporariamente;

XXIII - enviar ao Congresso Nacional o plano plurianual, o projeto de lei de diretrizes orçamentárias e as propostas de orçamento previstas nesta Constituição;

XXIV - prestar, anualmente, ao Congresso Nacional, dentro de sessenta dias após a abertura da sessão legislativa, as contas referentes ao exercício anterior;

XXV - prover e extinguir os cargos públicos federais, na forma da lei;

XXVI - editar medidas provisórias com força de lei, nos termos do art. 62 ;

XXVII - exercer outras atribuições previstas nesta Constituição.

Parágrafo único. O Presidente da República poderá delegar as atribuições mencionadas nos incisos VI, XII e XXV, primeira parte, aos Ministros de Estado, ao Procurador-Geral da República ou ao Advogado-Geral da União, que observarão os limites traçados nas respectivas delegações. (BRASIL, 1988).

Da análise do dispositivo supratranscrito, depreende-se que funções de Estado, governo e administração são expressamente designadas como atribuições do presidente. ${ }^{13}$ Com pretensão didática, José Afonso da Silva (2009, p. 549-550) utiliza

\footnotetext{
${ }^{13}$ Essa cumulação de funções é o traço essencial do presidencialismo. Sobre isso, ver item 1.1, supra.
} 
POLÍTICOS

essas funções como critério de classificação das atribuições presidenciais no sistema constitucional brasileiro: assim, atribuições inerentes à chefia de Estado seriam aquelas previstas no artigo 84, incisos VII, VIII, XVIII (segunda parte), XIV (no que tange à nomeação de ministros do Supremo Tribunal Federal e dos Tribunais Superiores), XV, XVI (primeira parte), XIX, XX, XXI e XXII; inerentes à chefia de governo seriam as atribuições previstas no artigo 84, incisos I, III, IV, V, IX, X, XI, XII, XIII, XIV (exceto quanto à nomeação de ministros do Supremo Tribunal Federal e dos Tribunais Superiores), XVII, XVIII (primeira parte), XXIII, XXIV e XXVII; por fim, inerentes à chefia da administração federal seriam as atribuições previstas no artigo 84, incisos II, VI, XVI (segunda parte), XXIV (que, em certo sentido, é também ato de administração, não apenas de governo) e XXV. ${ }^{14}$

\section{Aspectos JURÍdicos E POLÍTICOS DA POSSÍVEL ADOÇÃO DO SISTEMA PARLAMENTARISTA DE GOVERNO NO ATUAL QUADRO CONSTITUCIONAL BRASILEIRO}

O presidencialismo é, como visto, o modelo institucional adotado no Brasil. Seria ele, contudo, inarredável? E, mesmo que se admitisse a possibilidade de mudança, seria ela conveniente?

\subsection{Uma defesa da viabilidade da adoção do parlamentarismo por meio de emenda à} Constituição

No quadro constitucional atualmente desenhado no Brasil, uma eventual mudança no sistema de governo do país somente poderia ser feita (admitindo-se que ela seria possível) pela via da emenda constitucional. O referido instrumento encontra sua expressão no artigo 60 da Constituição, que estabelece:

Art. 60. A Constituição poderá ser emendada mediante proposta: I - de um terço, no mínimo, dos membros da Câmara dos Deputados ou do Senado Federal;

II - do Presidente da República;

III - de mais da metade das Assembléias Legislativas das unidades da Federação, manifestando-se, cada uma delas, pela maioria relativa de seus membros.

$\S 1^{0}$ A Constituição não poderá ser emendada na vigência de intervenção federal, de estado de defesa ou de estado de sítio.

\footnotetext{
${ }^{14}$ Nessa classificação, José Afonso da Silva não menciona a atribuição prevista no artigo 84, inciso XXVI (edição de medidas provisórias com força de lei). É impossível determinar se essa omissão teve caráter proposital ou se decorreu de um pequeno descuido. Entendemos que ela pode ser incluída entre as atribuições inerentes à chefia de governo, ressalvando, contudo, que se trata de um expediente anômalo, verdadeira usurpação da função legislativa que, em âmbito federal, é exercida pelo Congresso Nacional; problemática, portanto, não apenas do ponto de vista teórico, mas também do prático. $\mathrm{O}$ tema será retomado no item 2.2.1.
} 


\begin{abstract}
$\S 2^{\mathrm{o}}$ A proposta será discutida e votada em cada Casa do Congresso Nacional, em dois turnos, considerando-se aprovada se obtiver, em ambos, três quintos dos votos dos respectivos membros.

$\S 3^{\text {o }}$ A emenda à Constituição será promulgada pelas Mesas da Câmara dos Deputados e do Senado Federal, com o respectivo número de ordem.

$\S 4^{\underline{o}}$ Não será objeto de deliberação a proposta de emenda tendente a abolir:

I - a forma federativa de Estado;

II - o voto direto, secreto, universal e periódico;

III - a separação dos Poderes;

IV - os direitos e garantias individuais.

$\S 5^{\mathrm{o}}$ A matéria constante de proposta de emenda rejeitada ou havida por prejudicada não pode ser objeto de nova proposta na mesma sessão legislativa. (BRASIL, 1988).
\end{abstract}

O $\S 4^{\circ}$ do artigo 60 da Constituição traz um elenco de matérias que não podem ser objeto de emenda, vedando-se até mesmo a deliberação legislativa a respeito delas. São cláusulas pétreas, correspondentes a limitações materiais explícitas ao Poder Constituinte Derivado. ${ }^{15}$ Estaria o parlamentarismo entre elas?

A resposta é não. Pretender inviabilizar a adoção do parlamentarismo com fundamento no artigo 60, § $4^{\circ}$, III da Constituição, que trata da impossibilidade de abolição da separação de Poderes, equivaleria a conferir uma interpretação demasiado ampla à referida cláusula pétrea, que não se harmoniza com os métodos da hermenêutica constitucional. $O$ parlamentarismo, assim como $o$ presidencialismo, pressupõe a separação dos Poderes, distinguindo-se dele apenas na forma de conceber a relação entre Legislativo e Executivo. ${ }^{16}$

Muito mais difícil, entretanto, é a resposta à seguinte pergunta: seria o presidencialismo uma cláusula pétrea implícita da Constituição de 1988? Com efeito, é possível argumentar que, embora a questão atinente ao sistema de governo não se encontre expressamente no elenco de cláusulas pétreas, a realização do plebiscito de 1993 acabou por cristalizar o presidencialismo na ordem constitucional brasileira, e isso de tal modo que o regramento não possa ser objeto de alteração por via de emenda. O presidencialismo, assim, já faria parte do "núcleo duro" da Constituição. Essa posição pode ser entendida como a da "impossibilidade total" de mudança no sistema de governo. Uma posição mais branda, embora, do ponto de vista prático, muito próxima à anterior, admite que o sistema de governo possa ser alterado sem violação à ordem constitucional, mas

\footnotetext{
${ }^{15}$ A terminologia é de José Afonso da Silva (2009, p. 66).

${ }^{16}$ Ver itens 1.1 e 1.2, supra.
} 
POLÍTICOS

exige para isso a realização de um novo plebiscito, inadmitindo que a questão possa ser definida por meio de pura e simples emenda à Constituição. Subjaz a essa posição a ideia de que a democracia direta materializada nas consultas populares, das quais o plebiscito é uma das modalidades constitucionalmente admitidas (artigo 14, inciso I da Constituição), é superior à democracia representativa, cuja expressão está nas deliberações do parlamento. ${ }^{17}$

Quando analisadas com cuidado, porém, essas posições não parecem estar corretas. Embora o resultado do plebiscito de 1993, que consagrou, por expressiva maioria, o sistema presidencialista de governo, seja plenamente compreensível de um ponto de vista histórico, posto que realizado poucos anos depois do movimento "Diretas Já", cuja bandeira principal era, no ocaso do regime militar que oprimia o país há duas décadas, a volta da eleição direta para o cargo de presidente da República, seria um grave equívoco a superestimação do seu significado. Nada nesse fato pode levar à conclusão de que o sistema de governo deveria ser entendido como uma das partes graníticas da Constituição; aliás, a própria realização do plebiscito permite entrever a hesitação do Poder Constituinte Originário a esse respeito e a sua intenção de submeter a matéria à apreciação popular pelas vias democráticas. Por que essa apreciação deveria ocorrer somente em um único momento, ainda mais quando se toma em consideração o liame entre o sistema de governo e a história política de um povo, os diferentes estágios de desenvolvimento de sua democracia? ${ }^{18}$

Gize-se que a melhor doutrina costuma circunscrever as limitações tácitas ao Poder Constituinte Derivado àquelas matérias que se deixam reconduzir à própria integridade do sistema constitucional. Nesse sentido, Paulo Bonavides (2008, p. 202) afirma que tais limitações dizem respeito "à extensão da reforma, à modificação do processo mesmo de revisão e a uma eventual substituição do poder constituinte derivado pelo poder constituinte originário". Também José Afonso da Silva (2009, p. 68) envereda por esse caminho, estabelecendo que a Constituição implicitamente exclui do alcance do poder de reforma aqueles pontos cruciais que, se pudessem

\footnotetext{
17 Uma exposição dessas correntes de pensamento pode ser encontrada em BARCELLOS, 2020.

${ }^{18}$ Como salienta Bolívar Lamounier (1991, p. 10): “a nova Constituição brasileira, promulgada a 5 de Outubro de 1988, ratificou a opção feita quase 100 anos antes, quando a república presidencialista substituiu a monarquia parlamentarista como forma de governo. Dizer que a decisão tomada no dia 22 de março de 1988 foi surpreendente seria exagero: dizer, porém, que foi uma decisão ambígua, ou mesmo temporária, é ser inteiramente fiel aos fatos. Nem o debate que a antecedeu estava esgotado, nem muito menos a conjuntura da qual foi fruto conduzia a convicções inarredáveis entre os congressistas numa ou outra direção. Claro sintoma dessa ambiguidade foi a decisão notavelmente heterodoxa de incluir entre as 'disposições transitórias' do texto constitucional um artigo determinando a realização de um plebiscito, em 1993, para que o próprio eleitorado decida se quer presidencialismo ou parlamentarismo. Ou seja, a Constituição brasileira de 1988, ao contrário do que normalmente se espera de uma Constituição, manteve aberto, se é que não estimulou, o debate sobre a forma de governo."
} 
ser alterados pela via da emenda constitucional, implicariam uma subversão da lógica do sistema; a enumeração do autor compreende as limitações relativas à titularidade do Poder Constituinte Originário e Derivado e ao rito que deve ser seguido no processo de emenda à Constituição (admitindo, porém, que, nesse último caso, seja possível a reforma se ela tornar esse processo mais difícil ao invés de abrandá-lo). Em nenhum caso o sistema de governo é mencionado.

Saliente-se, ainda, que a realização de um novo plebiscito não pode ser tomada como requisito indispensável à alteração do sistema de governo, embora, evidentemente, possa ser interessante do ponto de vista da legitimação de tal mudança por meio da vontade popular manifestada expressamente. Do contrário, estabelecer-se-ia uma "hierarquização" entre a democracia direta e a democracia representativa que não encontra esteio no texto da Constituição, além de muito difícil de fundamentar do ponto de vista teórico. ${ }^{19}$ Trata-se, em última análise, de uma questão de conveniência política, não de imperativo constitucional.

\subsection{Seria a adoção do parlamentarismo conveniente para o Brasil?}

Estabelecida a viabilidade constitucional da adoção do parlamentarismo no país, o passo seguinte consiste em perguntar por sua conveniência.

Com essa pergunta, adentra-se terreno pantanoso. É possível afirmar objetivamente a superioridade de um sistema de governo sobre outro (do parlamentarismo sobre o presidencialismo, no caso)? Argumentos de Direito Constitucional Comparado não parecem, nesse âmbito, fazer muito sentido, pois não é tarefa difícil encontrar exemplos de nações em que o presidencialismo foi exitoso, sendo igualmente simples a identificação de experiências concretas de parlamentarismo pouco ou nada satisfatórias. Argumentação puramente empírica a favor de um ou de outro modelo enredar-se-ia fatalmente em insuperáveis contradições.

\footnotetext{
${ }^{19}$ Hans Kelsen, que, além de seu notório papel como jusfilósofo, foi um grande teorizador da democracia, chama a atenção para o fato de que a implantação de uma democracia representativa em estruturas humanas complexas como as sociedades modernas, em substituição à democracia direta, não implica uma perda substancial da liberdade política pelo povo; corresponde, na verdade, a um imperativo organizacional extremamente importante. A democracia não se cinge à liberdade irrestrita das assembleias dos cidadãos, como esse regime era concebido pelos antigos, mas pode perfeitamente ter lugar em um órgão colegiado, o parlamento, cuja formação ocorra através da participação popular, respeitando-se o princípio da maioria e o voto universal e igualitário. Por mais que a representação, nesse último caso, seja uma ficção, pela qual é atribuída ao parlamento a prerrogativa de exprimir a vontade do povo, semelhante expediente corresponde a uma "divisão do trabalho" indispensável em corpos sociais tecnicamente avançados; a liberdade política não é suprimida através dele, mas racionalmente organizada. A respeito, ver KELSEN, 2006, p. 175-179.
} 
POLÍTICOS

É possível, contudo, identificar nos pressupostos teóricos de cada um dos regimes de governo elementos que permitem caracterizá-los como mais ou menos adequados do ponto de vista do ideal democrático. Isso, todavia, não pode ser tomado como uma demonstração rigorosa da verdade; a adoção de um modelo institucional através de uma Constituição concreta e historicamente dada é, sem dúvida, uma questão que se reveste de caráter eminentemente político. Aqui, como ocorre com todos os problemas no âmbito do prático, é importante ter em mente o princípio aristotélico de que a exatidão não deve ser pretendida com a mesma intensidade em todos os objetos, mas apenas na extensão em que o próprio objeto o permite; seria, diz Aristóteles (2007, p. 39), igualmente despropositado exigir aproximações vagas de um geômetra e demonstrações inequívocas de um orador.

Feita a ressalva da impossibilidade de uma afirmação apodítica da superioridade de um sistema de governo sobre o outro, passa-se à exposição de alguns argumentos favoráveis ao parlamentarismo, condicionados pelo contexto político do Brasil atual e voltados a influir sobre essa realidade específica.

\subsubsection{As vantagens do parlamentarismo: Estado, governo, democracia e cultura política}

A primeira das vantagens do sistema parlamentarista é a nítida separação entre Estado e governo. Não se trata de mero capricho organizacional do poder, mas de expediente fundamental para a racionalidade das instituições, na medida em que ela possibilita a transcendência de uma chefia de Estado, supraideológica e suprapartidária, estável e conciliadora, ante os ventos sempre variáveis da política partidária, responsável pela formação do governo. $\mathrm{O}$ papel do chefe de Estado no exercício das funções tipicamente de governo pode ser mais ou menos dilatado, conforme se adote o parlamentarismo monista ou o dualista; ${ }^{20} \mathrm{em}$ ambos os casos, todavia, sua função primordial corresponde à personificação da unidade do Estado, representando-a e conservando-a, tanto do ponto de vista interno (perante a sociedade e os demais Poderes) quanto do externo (perante os Estados estrangeiros). (HESSE, 1998, p. 480). Em um país como o Brasil, marcado por profundas desigualdades sociais e regionais e por uma polarização crescente de sua política partidária, a importância da função conciliadora e representativa da unidade nacional exercida pelo chefe de Estado não deve ser subestimada.

Outra vantagem do parlamentarismo, que está em íntima conexão com a anterior, seria a interrupção do processo de, para usar as palavras de Miguel Reale (1962, p. 04), "hipertrofia crescente do Poder Executivo", verdadeira enfermidade institucional que acomete o Brasil há séculos. A Constituição de 1988, como já referido, ${ }^{21}$ não foi capaz de oferecer para ela um remédio adequado; seu texto contém uma lista colossal de competências privativas do presidente, abrangendo indiferentemente funções de Estado, governo e administração.

\footnotetext{
${ }^{20}$ Sobre essa distinção, ver item 1.2.2, supra.

${ }^{21}$ Ver supra, item 1.3.3.
} 
Nada há em nosso sistema constitucional que demonstre de modo tão nítido esse problema quanto a possibilidade de edição de medidas provisórias com força de lei (artigo 84, inciso XXVI, CRFB). Do ponto de vista do processo legislativo, a matéria encontra-se regulada no artigo 62 da Constituição, que estabelece os requisitos de "relevância e urgência" para que o presidente possa fazer uso desse instrumento, além de determinar sua imediata submissão ao Congresso Nacional. Na prática, porém, esse dispositivo constitucional converteu-se em uma espécie de "cheque em branco" para o titular do Poder Executivo, que, longe de restringir o seu emprego a medidas excepcionais, como estabelece o texto constitucional, não costuma revelar escrúpulos em promover o seu uso abusivo e indiscriminado, transformando-se em verdadeiro "legislador de exceção". Trata-se de uma inequívoca e funesta usurpação da função legislativa do Congresso, incompatível com o princípio da separação dos Poderes e com o próprio amadurecimento da democracia brasileira. (BONAVIDES, 2008, p. 685-686).

A hipertrofia do Poder Executivo tem sua inevitável contrapartida no amesquinhamento do Poder Legislativo. Não se pode olvidar, contudo, que a vontade legislativa do Parlamento, como caixa de ressonância das aspirações da sociedade, "de todas as vontades políticas no sistema representativo é a mais legítima" (BONAVIDES, 2008, p. 685); sufocá-la equivale a embaraçar o funcionamento da própria democracia, corroída em suas bases pela vocação autocrática do Poder Executivo (que não se abranda, antes se reforça, pelo fato de ser o seu titular legitimado por eleições diretas). ${ }^{22}$

${ }^{22} \mathrm{O}$ parlamentarismo, aliás, é capaz de mitigar fortemente o viés autocrático do Poder Executivo, já que nele o governo constitui "um corpo coletivo orgânico, de sorte que as medidas governamentais implicam a atividade de todos os Ministros e de seus Ministérios". (SILVA, 2009, p. 506). É o governo de gabinete, não o governo do primeiro-ministro; embora sob a chefia desse último, as decisões relativas à condução dos assuntos governamentais são tomadas em conjunto pelos membros do conselho, através de reflexão e deliberação. Nada mais distante disso que o "governo de um homem só" materializado no presidencialismo, no qual as decisões mais importantes para a nação recaem sobre os ombros de uma única pessoa. No Brasil, como expõe Raul Machado Horta (2010, p. 653), essa foi a autocompreensão do presidencialismo desde os seus primórdios: “Na Primeira República, Campos Salles fixou a doutrina do governo presidencial, acentuando que, 'neste regime, não há no Governo senão a política do Presidente: o que cabe aos Ministros é praticar lealmente esta política, para que se estabeleça a homogeneidade governativa'. Governo do Presidente e não Governo do Conselho de Ministros, que Campos Salles repelia, sob o argumento de 'que, sob o regime presidencial, sempre se me afigurou absurda a deliberação em Conselho de Ministros. A ação coletiva neste caso, absorvendo a autoridade presidencial, que assim se deixaria eliminar pelo voto ministerial, importa na mais flagrante infração do preceito substancial, que concentra a responsabilidade legal na pessoa do Presidente.'" Diante dessa característica do presidencialismo, João Camillo de Oliveira Torres (1962, p. 36) assevera: "Todo 
POLÍTICOS

Esse vício do presidencialismo, aliás, motivou o profundo desencanto daquele que, como o cérebro por trás da Constituição de 1891, introduziu-o no país, o notável jurista Rui Barbosa. Em discurso proferido no ano de 1917, lamentou o grande publicista o fato de que "a tribuna parlamentar é, hoje em dia, uma cratera extinta, e as câmaras legislativas mera sombra de representação nacional." (BARBOSA, 1999, p. 15-16).

Rui Barbosa tinha inspirações nitidamente norte-americanas, grande admirador que era do modelo institucional desenhado nos Estados Unidos da América. Para fazer justiça a semelhante modelo, contudo, é importante salientar que ele nunca foi fielmente seguido no Brasil. Por aqui, durante a maior parte do período correspondente à Primeira República, o presidente não representava mais do que uma espécie de delegado das oligarquias regionais, o que explica a relativa discrição das presidências até 1930; com o golpe de Estado encabeçado por Getúlio Vargas naquele ano, porém, a instituição presidencial adquiriria novos contornos, agigantando-se na vida política brasileira de um modo que não pode ser correlacionado com o modelo norte-americano. Desde então, o Brasil conhece apenas - na terminologia empregada por Bolívar Lamounier - uma forma "plebiscitária" de presidencialismo, no qual a eleição direta do presidente propicia a existência de um Poder Executivo extremamente personalizado, espécie de centro de gravidade de todo o sistema político, sempre reivindicador de uma superioridade em relação ao Poder Legislativo que, no papel, não lhe é conferida pela Constituição. A exemplo do Brasil, os demais países latino-americanos também enveredaram pelo caminho do presidencialismo plebiscitário, cujo contraste com o sistema norte-americano, fortemente baseado no equilíbrio entre os Poderes e no sistema de checks and balances, não poderia ser mais nítido. (LAMOUNIER, 1992, p. 52).

Em um sistema de presidencialismo como o brasileiro, o Poder Legislativo apequena-se não apenas do ponto de vista institucional, sufocado pelo gigantismo usurpador e autocrático do Poder Executivo; degrada-se também moralmente. No país, os males advindos dessa situação sempre se fizeram presentes, embora as crises políticas mais recentes tenham-nos colocado particularmente em evidência. Não tendo o Congresso a faculdade de destituir (salvo em caso de crime de responsabilidade) o chefe do Poder Executivo, mesmo que a maioria parlamentar não seja favorável ao governo do dia, e dependendo o presidente de apoio no Legislativo para levar adiante seus projetos de governo, o parlamento acaba por converter-se em campo aberto para o fisiologismo e as negociações espúrias. Não é

poder, dizia Lord Acton, sábio historiador inglês - todo poder corrompe e todo poder absoluto corrompe absolutamente. O mesmo dirá, com outras palavras, Alain, filósofo francês: 'Um tirano pode ser eleito pelo sufrágio universal e não ser menos tirano por isso. O que importa não é a origem dos poderes, mas o controle continuado e eficaz que os governados exercem sobre os governantes'. E isso só é possível no parlamentarismo." 
preciso dizer o quanto isso tende a tornar mais dramático o quadro da corrupção, um dos males históricos do Brasil. Como salienta Paulo Bonavides (2008, p. 214):

No parlamentarismo as Câmaras legislativas são escolas de pedagogia cívica, no presidencialismo elas se transformam em mercado de clientelismo, onde o tráfico de influência e o jogo de interesses convergem ali para fazê-las submissos e servis apêndices do Poder Executivo.

Por trás dessa situação esconde-se um grave desequilíbrio entre Executivo e Legislativo, em desfavor desse último. ${ }^{23} \mathrm{~A}$ restauração do equilíbrio entre os Poderes é tarefa muito menos complexa no parlamentarismo; nele, mais do que simples repartição, no sentido clássico da divisão dos Poderes, o que há é uma integração entre Legislativo e Executivo, na medida em que o chefe de governo corresponde, em última análise, ao líder da maioria parlamentar, dispondo o parlamento de amplos mecanismos de fiscalização e controle sobre ele e seu gabinete. (TORRES, 1962, p. 15-16).

Com isso, uma vantagem adicional do parlamentarismo pode ser vista claramente. Ao pressupor um governo de responsabilidade coletiva, ele resolve o problema do viés autocrático do Poder Executivo, marca indelével do presidencialismo. O gabinete é, no parlamentarismo, considerado em seu conjunto (constitui-se como um bloco e dissolve-se da mesma forma), o que o torna, como um tomador de decisões na esfera governamental, verdadeiro palco de deliberação. Além disso, como o governo somente se sustenta enquanto tiver o apoio da maioria parlamentar, o próprio parlamento participa, em certo sentido, do governo, podendo inclusive recusar-lhe a continuidade. (TORRES, 1962, p. 17). A opinião pública é, nesse âmbito, de suma importância, já que, escolhidos através de eleição popular direta, os membros do parlamento precisam levar em conta, por motivos estritamente eleitorais, a vontade dos representados em suas relações com o gabinete. Há, assim, uma nítida cadeia de responsabilidades, do gabinete perante o parlamento e do parlamento perante o povo. (PILLA, 1992, p. 38). Do ponto de

\footnotetext{
${ }^{23}$ Juan José Linz e Larry Diamond mencionam como um dos principais problemas políticoinstitucionais da América Latina a atrofia das câmaras legislativas, muitas vezes reduzidas a um papel insignificante diante de poderes presidenciais sempre crescentes. Os autores veem inclusive um fator de instabilidade na tentativa de quebra desse ciclo; o presidencialismo latino-americano é pródigo em exemplos de casos nos quais o Poder Legislativo, ao procurar afirmar sua autoridade em face do Poder Executivo, acabou por gerar uma grave crise institucional e, com isso, o colapso do próprio regime democrático. Foi, segundo os mencionados autores, o que ocorreu, em maior ou menor grau, na Colômbia em 1949, no Brasil em 1964, no Peru em 1968 e no Chile em 1973. (DIAMOND; LINZ, 1989, p. 26).
} 
POLÍTICOS

vista democrático, as vantagens desse modelo institucional dificilmente podem ser postas em dúvida.

Mencionou-se que, no sistema parlamentarista de governo, o parlamento pode recursar ao gabinete a continuidade. Nisso reside talvez a vantagem mais visível do parlamentarismo: a possibilidade de destituição, pacífica e desembaraçada, de um governo disfuncional. O presidencialismo é o governo da irresponsabilidade política do presidente; eleito e empossado, não pode ele ser destituído do cargo por motivos políticos, mesmo que encontre ferrenha oposição no Legislativo e inequívoca desaprovação da opinião pública. (PILLA, 1992, p. 34). No parlamentarismo, ao contrário, o governo é inteiramente dependente da confiança política da nação, corporificada no parlamento. Por meio do instituto da responsabilidade ministerial, ao parlamento é facultado, em um juízo estritamente político, renovar ou recusar essa confiança; recusando-a, o gabinete não pode subsistir. (BONAVIDES, 2008, p. 213). ${ }^{24}$

O presidencialismo não conhece a responsabilidade política do chefe de governo. Por mais desastroso que seja o seu modo de exercer o cargo, não há como destituí-lo antes do término do mandato. $\mathrm{O}$ instrumento mais próximo da moção de censura do parlamentarismo que o sistema presidencialista conhece é o processo de impeachment; ele, contudo, não tem, como aquela, natureza inteiramente política, sendo, ao menos em parte, um procedimento jurídico. No presidencialismo, a responsabilidade do chefe de governo é somente criminal, ou seja, a possibilidade de sua destituição do cargo pressupõe uma violação à lei positiva: a prática de um dos delitos expressamente previstos em lei como crimes de responsabilidade. Se, contudo, o presidente não comete crime de responsabilidade algum, não pode ele ser afastado do cargo, mesmo incorrendo em desmandos políticos que, em um sistema funcional, ensejariam inevitavelmente sua destituição. (PILLA, 1992, p. 34). O impeachment de um presidente sem o correspondente crime de responsabilidade implica violação à ordem constitucional e desrespeito à própria essência do regime.

A insuficiência dessa responsabilidade exclusivamente criminal do presidente revela-se de modo gritante nas recentes experiências do presidencialismo brasileiro. Desde o advento da atual Constituição, em 1988, o Brasil elegeu, até o momento, cinco presidentes, dos quais nada menos que dois foram afastados do cargo por impeachment (embora um deles tenha optado pela renúncia antes do desfecho do processo). Em ambos os casos, a crise que motivou o afastamento foi acompanhada de forte comoção nacional; a última e mais recente delas, ocorrida em 2016, foi particularmente traumática, gerando na sociedade brasileira uma polarização

${ }^{24}$ É possível que, sob certas circunstâncias, o governo não concorde com sua demissão; nesse caso, julgando-se detentor de apoio da opinião pública, pode ele requerer ao chefe de Estado a dissolução do parlamento e a convocação de eleições extraordinárias para a formação de um novo parlamento. O que importa salientar é que, mesmo para semelhantes situações de crise, o parlamentarismo dispõe de mecanismos adequados de solução pelas próprias vias políticas. (SILVA, 2009, p. 507). 
ideológica raramente vista antes. Parece ser um fato incontestável que nosso modelo de presidencialismo vem se mostrando incapaz de restringir as crises ao meio político, o que evitaria que elas repercutissem com grande intensidade nos aspectos sociais e econômicos do país. Não poderia ser diferente; como salienta José Afonso da Silva (2009, p. 507), "é certo que o sistema presidencialista não é institucionalmente apto para enfrentar graves situações de crise, [...] nem para assegurar a estabilidade, a continuidade e a eficácia de uma democracia pluralista, como a que foi instituída na Constituição."

O processo de impeachment, que, como já referido, não pode estar ligado à responsabilidade política do presidente, é, por menos satisfatórios que sejam seus efeitos, um instituto coerente com os pressupostos do presidencialismo, sistema de governo que estabelece uma rígida separação entre o Poder Executivo e o Poder Legislativo. Não poderia ser mais forte o contraste com o parlamentarismo, que pressupõe a integração entre esses Poderes e, com isso, fornece mecanismos ágeis de superação das crises. ${ }^{25} \mathrm{O}$ parlamentarismo é o sistema da flexibilidade, enquanto o presidencialismo, o da rigidez.

A flexibilidade na adoção de soluções, de forma imediata, para superar as crises e os impasses políticos, também se faz presente no parlamentarismo [...]. Pode-se dizer que a prática do regime parlamentar corresponde a um esforço de aperfeiçoamento constante das instituições. É o regime do debate e da oralidade e exige do homem público o frequente exercício da palavra. A flexibilidade no funcionamento e a rápida adaptação às mutações demonstram o dinamismo do regime parlamentar. É o regime de Governo mais adequado às sociedades em mudança e o mais apto a promover mudanças sem o sacrifício da liberdade. (HORTA, 2010, p. 640-641).

Em adição a isso, é possível, recuando um pouco mais na história políticoinstitucional do Brasil, já abordada no presente estudo, ${ }^{26}$ formular, embora com os

\footnotetext{
${ }^{25}$ Nesse sentido, dados empíricos parecem demonstrar que o colapso da democracia diante de situações de grave tribulação institucional é muito menos frequente no parlamentarismo que no presidencialismo. Juan José Linz e Alfred Stepan (1996, p. 141) assinalam que, entre os 41 países do mundo que tiveram democracias ininterruptas ao longo da década de 1980, nada menos do que 30 adotavam sistemas parlamentaristas em sua forma pura, contra apenas 4 de sistema presidencialista puro. Mais além, entre os 93 países que conquistaram sua independência entre 1945 e 1979, apenas 15 mantiveram intacta a democracia durante toda a década de 1980; os que lograram fazê-lo adotavam, sem exceção, o parlamentarismo.

${ }^{26}$ Ver item 1.3, supra.
} 
POLÍTICOS

devidos cuidados, um argumento histórico em favor do parlamentarismo. Não é de hoje que o presidencialismo brasileiro constitui verdadeiro fator de instabilidade para o país; sucessivas foram as crises que, ao longo de nossa história, tiveram nele o seu epicentro. No enfrentamento da questão, Bonavides é particularmente duro:

Quanto ao presidencialismo, é modelo malogrado que ao longo de cem anos de república demonstrou ser a mais nociva e inidônea das formas usuais de governo, pelo menos no atual grau de desenvolvimento da sociedade brasileira. Outra coisa ele não fez aqui senão gerar no ventre de suas crises a ditadura, a sedição militar, o tumulto social, a rigidez oligárquica e uma sensível atrofia do sentimento de responsabilidade pública nos titulares do poder. (BONAVIDES, 2008, p. 220).

Bolívar Lamounier, por sua vez, ao discorrer acerca das vicissitudes da história institucional do Brasil ao longo do século $X X$, marcada pela alternância de períodos de relativa normalidade democrática com outros de ameaça golpista, ditadura e supressão das liberdades, sublinha a relação entre semelhante quadro de instabilidade e a insistência no modelo presidencialista, muito menos favorável que o parlamentarista à solução dos dilemas inerentes à institucionalização da democracia em sociedades complexas, especialmente no que tange ao reconhecimento da mútua legitimidade das principais forças políticas que lutam entre si pelo poder. Não é nenhuma coincidência, afirma o autor, que Getúlio Vargas, Jânio Quadros e João Goulart, três dos cinco presidentes do período que vai de 1945 a 1964, tenham encerrado seus mandatos, por coação ou vontade própria, sob circunstâncias evidentemente anômalas. (LAMOUNIER, 1994, p. 3738).

Por fim, não deve ser negligenciada a influência da adoção de um sistema de governo parlamentarista sobre aspectos culturais da participação política do povo brasileiro. Sob esse prisma, pode-se dizer que, no Brasil, o desenvolvimento pleno da democracia vem sendo continuamente obstado pelo presidencialismo; como aduz Miguel Reale (1962, p. 04), esse regime acaba "dificultando a educação cívicopolítica de nosso povo, tristemente habituado a decidir-se mais por homens do que por ideias". Com efeito, a eleição de um chefe de governo que é simultaneamente chefe de Estado, dotado de competências extremamente dilatadas, além de irresponsável politicamente perante o parlamento, acaba por favorecer a personalização do poder e, com ela, a atuação de pretensos "salvadores da pátria". Isso significa que, nas campanhas eleitorais, os holofotes não são dirigidos para a discussão racional de distintas propostas de governo, mas para a pessoa do candidato, sendo que, quanto mais messiânicos forem os dotes que demonstrar, 
maior vantagem, em princípio, ele terá. ${ }^{27}$ Além, naturalmente, do maniqueísmo que caracteriza as disputas eleitorais: o eleitor tende a ver seu candidato como a encarnação de todas as virtudes e seu adversário como a encarnação de todos os vícios, uma visão distorcida que, não raro, os próprios candidatos alimentam. ${ }^{28} \mathrm{O}$ resultado disso é uma desconcertante "infantilização" do processo democrático.

O parlamentarismo não tende a essa personalização extrema do poder. Nele, chefe de Estado e chefe de governo são pessoas distintas; além disso, o próprio governo é exercido em conjunto pelos membros do gabinete, o qual, por sua vez, é responsável politicamente perante o parlamento. Do ponto de vista da educação política do eleitorado e do aprimoramento do processo democrático, essa divisão de funções é essencial. Em linguagem forte, Sérgio Buarque de Holanda (1995, p. 60) salientou que a "democracia no Brasil foi sempre um lamentável malentendido". Na medida em que se pretende transformar o Brasil em uma autêntica

${ }^{27}$ Essa curiosa característica do processo político brasileiro faz ecoar, com respeito à nossa tradição portuguesa, o mito do sebastianismo, segundo o qual o Rei D. Sebastião, desaparecido no norte da África em 1578, retornará para resgatar Portugal da decadência e devolver-lhe seu papel de destaque entre as nações. Fernando Pessoa traduziu esse mito, de forma particularmente bela, nos versos de um dos poemas que integram a obra "Mensagem": "Levando a bordo El-Rei D. Sebastião,/E erguendo, como um nome, alto o pendão/Do Império,/Foi-se a última nau, ao sol aziago/Erma, e entre choros de ânsia e de pressago/Mistério./Não voltou mais. A que ilha indescoberta/Aportou? Voltará da sorte incerta/Que teve?/Deus guarda o corpo e a forma do futuro,/Mas Sua luz projeta-o, sonho escuro/E breve./Ah, quanto mais ao povo a alma falta,/Mais a minha alma atlântica se exalta,/E entorna,/E em mim, num mar que não tem tempo ou 'spaço,/Vejo entre a cerração teu vulto baço/Que torna./Não sei a hora, mas sei que há a hora,/Demore-a Deus, chame-lhe a alma embora/Mistério./Surges ao sol em mim, e a névoa finda:/A mesma, e trazes o pendão ainda/Do Império." (PESSOA, 2010, p. 76-77).

${ }^{28}$ Sobre as campanhas eleitorais no presidencialismo, João Camillo de Oliveira Torres (1962, p. 26) lança observações de surpreendente atualidade: “Uma eleição presidencial é dominada por fatores que confundem o eleitorado. Em primeiro lugar, há duas ou três opções únicas, soluções que, muitas vezes, não agradam ao eleitor médio, forçado a escolher por exclusão; vota-se no menos mau. Como se isso não fosse suficiente, os eleitores não conhecem realmente os candidatos. São pessoas faladas, populares, em evidência, mas, no fim de algum tempo, podem revelar uma personalidade fictícia, criada pela propaganda. Modernamente, quando alguém se transforma em nome nacional, podemos dizer que estamos diante de uma figura mitológica, de uma criatura inventada pela propaganda. [...] os eleitores costumam ler somente os jornais de sua corrente, os quais, por força da natureza das coisas e de acordo com as regras bem conhecidas de propaganda política, simplificam a imagem para convencer melhor. O resultado é que vemos, habitualmente, uma figura absolutamente falsa. O homem da rua costuma sentir um ódio desordenado pelo político adversário, como se este fosse um monstro horrível [...]. Daí detestarmos certos políticos que outras pessoas admiram sinceramente." 
POLÍTICOS

democracia (o que, aliás, é exigência expressa do artigo $1^{\circ}$, caput, da Constituição de 1988, segundo o qual a República Federativa do Brasil constitui-se em Estado Democrático de Direito), isso somente pode ter seus alicerces nas instituições e no povo, um povo corporificado em um eleitorado amadurecido, capaz de expressar sua vontade livre e desembaraçadamente, decidindo em primeiro lugar por ideias, não por pessoas.

\subsubsection{Duas objeções possíveis}

Apesar das aludidas vantagens, é possível identificar alguns pontos relevantes de discórdia a respeito da conveniência da adoção do sistema de governo parlamentarista no Brasil. Dois deles serão tratados a seguir, oferecendo-se a ambos uma tentativa de resposta.

A mais frequente crítica que se dirige ao parlamentarismo enquanto sistema diz respeito à instabilidade dos gabinetes. Com efeito, sendo o gabinete responsável politicamente perante o parlamento, pende continuamente sobre o governo a possibilidade de uma moção de censura que o derrube; um parlamento pode, teoricamente, usar dos mecanismos à sua disposição para demitir sucessivos gabinetes em um período muito exíguo, impedindo-os de desenvolver adequadamente os respectivos programas de governo. Risco semelhante não existe no presidencialismo, onde o governo é eleito a prazo certo. ${ }^{29}$

Todavia, é importante ressaltar que, diante de semelhante abuso de poder do parlamento, gerador de incertezas e instabilidade, o governo não necessariamente deve estar desarmado; acreditando ele ter o apoio da opinião pública, pode apresentar ao chefe de Estado o pedido de dissolução do parlamento. Ou seja, se o gabinete não é politicamente irresponsável, tampouco o é a própria instituição parlamentar. (PILLA, 1992, p. 38). Essa prerrogativa do gabinete, como seria de se esperar, acaba por frear as investidas constantes e irrefletidas do Legislativo, mitigando consideravelmente a instabilidade do regime.

Além disso, essa instabilidade dos governos frequentemente está ligada a uma causa bem específica: a multiplicidade de partidos políticos. Com efeito, um grande número de partidos pode, no melhor dos casos, conduzir à formação de governos de coalizão, mas, no pior deles, pode comprometer a formação de uma maioria parlamentar estável, dificultando, por consequência, a formação e permanência dos gabinetes. (TORRES, 1962, p. 33). Por essa razão, a questão da limitação do número de partidos políticos com representação no parlamento reveste-se de considerável urgência no parlamentarismo. Gize-se, contudo, que o problema pode ser resolvido, sem grandes dificuldades, através da adoção de uma adequada cláusula de barreira. $^{30}$

\footnotetext{
${ }^{29}$ Ver itens 1.1 e 1.2, supra.

${ }^{30}$ Para melhor enfrentamento dessa questão específica, remete-se o leitor às considerações presentes em LAMOUNIER, 1992, p. 53-55.
} 
Cumpre fazer uma derradeira observação a esse respeito. Por mais que o parlamentarismo disponha de mecanismos institucionais sutis para evitar o problema da instabilidade dos gabinetes, trata-se de um risco que, nesse regime de governo, não pode ser de todo eliminado. Seria um erro, todavia, superestimá-lo. Nas palavras de Pilla (1992, p. 42),

Não creio que, a não ser em condições excepcionais, convenha que um governo dure mais de dois anos. Ainda os melhores governos gastam-se rapidamente com o tempo, tais são os interesses que contrariam, os descontentamentos que geram, e os erros que fatalmente praticam. Assim sendo, quem deixaria de trocar por um novo o automóvel ao cabo de três ou quatro anos de uso, se pudesse fazê-lo sem ônus? Não é preferível substituir o governo, enquanto não envelheceu, a suportá-lo obrigatoriamente durante um ou dois anos, depois de decrépito?

Uma segunda objeção que poderia ser levantada diz respeito à importância das instituições. Os defensores do parlamentarismo, segundo essa objeção, estariam iludidos em relação ao alcance do papel que um regime de governo pode desempenhar; os males da vida política adviriam antes de pessoas que de instituições, e seria ingenuidade supor que uma melhora pudesse ocorrer apenas com a troca do sistema de governo, sem a substituição das pessoas e dos grupos que dominam o jogo político.

Um defensor dessa ideia poderia reconduzir sua objeção a uma espécie de "sacralização" das instituições jurídicas, que deliberadamente ignora a realidade sobre a qual essas instituições devem atuar. Em contexto semelhante, afirma Sérgio Buarque de Holanda (1995, p. 178-179):

Escapa-nos esta verdade de que não são as leis escritas, fabricadas pelos jurisconsultos, as mais legítimas garantias de felicidade para os povos e de estabilidade para as nações. Costumamos julgar, ao contrário, que os bons regulamentos e a obediência aos preceitos abstratos representam a floração ideal de uma apurada educação política, da alfabetização, da aquisição de hábitos civilizados e de outras condições igualmente excelentes. No que nos distinguimos dos ingleses, por exemplo, que, não tendo uma constituição escrita, regendo-se por um sistema de leis confuso e anacrônico, revelam, contudo, uma capacidade de disciplina espontânea sem rival em nenhum outro povo.

[...] 


\begin{abstract}
Nesse erro se aconselharam os políticos e demagogos que chamam atenção frequentemente para as plataformas, os programas, as instituições, como únicas realidades verdadeiramente dignas de respeito. Acreditam sinceramente que da sabedoria e sobretudo da coerência das leis depende diretamente a perfeição dos povos e dos governos.
\end{abstract}

Semelhante objeção certamente encerra um fragmento de verdade. Ela, entretanto, não deve ser acolhida integralmente, na medida em que subestima o papel das instituições e superestima o das pessoas. Enfrentando a questão, Raul Pilla (1992, p. 11) sustenta:

Há, realmente, quem assim pense: negam toda influência ao regime político e tudo fazem depender dos homens. É, porém, uma opinião tão errônea como a que tudo reduzisse ao regime e por completo abstraísse dos homens que o tem de praticar. Completam-se as duas cousas e devem, por isto, harmonizar-se. A eficiência, a produtividade de uma fábrica não está, apenas, nos seus operários; também está na sua administração e na sua maquinaria. Tomai certos homens, levai-os de uma fábrica obsoleta e mal gerida para estabelecimento moderno e modelar, e eles já não serão os mesmos operários: produzirão mais e melhor. Como afirmar que, na vida pública, tudo se reduz aos homens e nenhuma importância tem o mecanismo político?

Boas instituições não melhoram pessoas deletérias, mas instituições ruins, com toda a certeza, potencializam os efeitos de pessoas deletérias. Por si só, tal circunstância já torna imperiosa a sua substituição por instituições melhores.

\title{
4. CONCLUSÃo
}

A crise política vivida pelo Brasil nos últimos anos pode, em grande parte, ser atribuída ao modelo institucional adotado no país. $\mathrm{O}$ esgotamento do presidencialismo brasileiro não é um fenômeno recente; seus efeitos profundamente deletérios, contudo, tornaram-se mais evidentes através da presente crise, e é lícito pensar que, se mantido esse sistema, novas tribulações institucionais terão origem em seu seio.

Autores clássicos e contemporâneos do pensamento jurídico e político brasileiro defenderam a adoção do regime parlamentarista como o melhor modelo institucional para o Brasil. Essa posição foi defendida também no presente estudo, com a exposição de um juízo afirmativo a respeito da viabilidade constitucional de uma mudança no sistema de governo do país, bem como de uma série de argumentos voltados a demonstrar a conveniência de semelhante alteração. Sucintamente, a adoção do parlamentarismo pode, de acordo com a tese aqui 
defendida, ser vista como um imperativo de racionalidade institucional, de grande importância para a consolidação e o aprofundamento da jovem democracia brasileira.

Cumpre ressaltar, entretanto, que não se trata de uma "solução mágica", uma panaceia para todos os males da política nacional, como se vê frequentemente em defesas exaltadas do parlamentarismo, muitas delas mais emocionais que racionais. É lícito supor que as virtudes de um novo sistema de governo não se façam sentir imediatamente após a sua adoção; trata-se de um trabalho contínuo de aperfeiçoamento institucional, cujos frutos, provavelmente, serão visíveis apenas no médio ou no longo prazo. É da simbiose entre a racionalidade institucional e a educação política do povo que um novo horizonte pode se abrir.

Naturalmente, nada foi dito no presente trabalho a respeito das características concretas que um sistema parlamentarista de governo deveria adotar (se monista ou dualista, mais centralizador ou mais democrático), tampouco das numerosas alterações constitucionais que deveriam acompanhar a mudança de regime (como aquelas relativas ao sistema eleitoral e à estrutura governamental das unidades da federação, apenas para mencionar dois exemplos). Essas são questões que, embora extremamente importantes, devem ser dirimidas em um passo seguinte, que não será dado no presente estudo.

Às vozes discordantes, o encerramento deste texto é um convite ao diálogo. A institucionalização da democracia no Brasil é ainda muito recente, e o caminho para sua consolidação passa necessariamente pelo debate acerca das instituições e do seu papel na construção de um país mais livre, plural, justo e solidário. Quanto mais abrangente e qualificado for o debate nesse campo, maior será o ganho para o desenvolvimento das nossas instituições e, por extensão, do nosso processo democrático.

\section{REFERÊNCIAS}

ARISTÓTELES. Ética a Nicômaco. Tradução de Edson Bini. 2. ed. Bauru: EDIPRO, 2007.

ALVES FILHO, F. Rodrigues. O Que É Parlamentarismo: Doutrina e Prática no Mundo. São Paulo: Obelisco, 1961.

AZEVEDO, Fay de. Democracia e Parlamentarismo. Porto Alegre: Centro da Boa Imprensa do Rio Grande do Sul, 1934. 
BARBI, Celso Agrícola. Do Mandado de Segurança. 12. ed. Rio de Janeiro: Forense, 2009.

BARBOSA, Rui. Osvaldo Cruz. Rio de Janeiro: Fundação Casa de Rui Barbosa, 1999.

BARCELLOS, Ana Paula de. Ana Paula de Barcellos - Sistema de Governo como Cláusula Pétrea, 12 fev. 2020. Vídeo em meio eletrônico (8min57s), son., color. Disponível em: <https://www.youtube.com/watch?v=M1TTslDZfqo>. Acesso em: 10 set. 2020.

BONAVIDES, Paulo. Curso de Direito Constitucional. 23. ed. São Paulo: Malheiros, 2008.

BRASIL. Constituição. Constituição da República Federativa do Brasil (1988).

CARVALHO, José Murilo de. A Formação das Almas: o Imaginário da República no Brasil. São Paulo: Companhia das Letras, 1990.

CONSTANT, Benjamin. Curso de Política Constitucional. Tomo I. Traducción de D. Marcial Antonio Lopez. Madrid: Imprenta de la Compañía, 1820.

DIAMOND, Larry; LINZ, Juan J. Introduction: Politics, Society, and Democracy in Latin America. in: DIAMOND, Larry; LINZ, Juan J.; LIPSET, Seymour Martin. Democracy in Developing Countries: Vol. 4, Latin America. Boulder: Lynne Rienner; London: Adamantine, 1989.

HESSE, Konrad. Elementos de Direito Constitucional da República Federal da Alemanha. Tradução de Luís Afonso Heck. Porto Alegre: Sergio Antonio Fabris, 1998.

HORTA, Raul Machado. Direito Constitucional. 5. ed. Belo Horizonte: Del Rey, 2010.

KELSEN, Hans. Von Wesen und Wert der Demokratie (2. Auflage 1929). in: Idem. Verteidigung der Demokratie. hrsg. von Matthias Jestaedt und Oliver Lepsius. Tübingen: Mohr Siebeck, 2006. 
LAMOUNIER, Bolívar. E no Entanto se Move: Formação e Evolução do Estado Democrático no Brasil, 1930-94. in: LAMOUNIER, Bolívar; CARNEIRO, Dionísio Dias; ABREU, Marcelo de Paiva (org.). 50 Anos de Brasil, 50 Anos de Fundação Getulio Vargas. Rio de Janeiro: Fundação Getulio Vargas, 1994.

LAMOUNIER, Bolívar. O Modelo Institucional dos Anos 30 e a Presente Crise Brasileira. in: Estudos Avançados, v. 6, n. 14, 1992.

LAMOUNIER, Bolívar. Parlamentarismo ou Atenuação do Presidencialismo: Notas sobre o Debate Brasileiro Recente. in: Revista do Instituto de Estudos Brasileiros, n. 32, 1991.

LINZ, Juan J.; STEPAN, Alfred. Problems of Democratic Transition and Consolidation: Southern Europe, South America, and Post-Communist Europe. Baltimore; London: Johns Hopkins University, 1996.

MIRKINE-GUETZÉVITCH, B. As Novas Tendências do Direito Constitucional. Tradução de Candido Motta Filho. São Paulo: Companhia Editora Nacional, 1933.

MONTESQUIEU, Baron de. O Espírito das Leis: As Formas de Governo, a Federação, a Divisão dos Poderes. Tradução de Pedro Vieira Mota. 8. ed. São Paulo: Saraiva, 2004.

PESSOA, Fernando. Mensagem. Porto Alegre: L\&PM, 2010.

PILLA, Raul. Catecismo Parlamentarista. Porto Alegre: Assembleia Legislativa do Rio Grande do Sul, 1992.

REALE, Miguel. Parlamentarismo Brasileiro. São Paulo: Saraiva, 1962.

SILVA, José Afonso da. Curso de Direito Constitucional Positivo. 32. ed. São Paulo: Malheiros, 2009.

TORRES, João Camillo de Oliveira. Cartilha do Parlamentarismo. Belo Horizonte: Itatiaia, 1962. 